\title{
The effect of nutrition on the seasonality of reproduction in ewes
}

\author{
Fernando FORCADA*, José-Alfonso ABECIA \\ Departamento de Producción Animal y Ciencia de los Alimentos, Universidad de Zaragoza, \\ Miguel Servet 177, 50013 Zaragoza, Spain
}

\begin{abstract}
The beneficial effects of nutrition on reproduction in sheep have been described, particularly on ovulation rate. However, the relationships between nutrition and reproductive seasonality are not well known. This review will deal with the effects of body fat or food intake on sexual and hypothalamic/pituitary activity in sheep, mainly focused on Mediterranean genotypes. Although only severe malnutrition can significantly extend the length of the seasonal anestrous period, the level of fat reserves can play a significant role on reproductive seasonality delaying the onset of seasonal anoestrus, particularly on the Mediterranean environment. The effect of overfeeding on LH secretion has also been reported, specially at short term. Several experimental approaches have elucidated that both high body fat and food intake are able to modify the sensitivity of the hypothalamus to oestradiol negative feedback during seasonal anoestrus, with those effects being associated to a reduced amount of NPY mRNA and to an increase of plasma insulin, glucose and leptin concentrations, particularly in the late scenario. However, the highest receptivity to nutritional stimulation in terms of increasing LH occurs when ewes are subjected to a photoperiodic state of early anoestrus or late breeding season rather than under a photoperiod characteristic of the end of anoestrus or the beginning of the breeding season.
\end{abstract}

sheep / nutrition / reproductive seasonality / gonadotropins

\section{INTRODUCTION}

The main reason a species has a seasonal pattern of reproduction is to insure that births occur at the optimal time of the year, usually spring, which allows the newborn to grow under favourable conditions of temperature and food availability in advance of the winter. The breeding season of ewes is a succession of 16-18 d oestrous cycles, which usually begins in the late summer or early autumn and ends in the late winter or early spring. Domestication has produced a shift in the timing of the breeding season from the autumn to summer, although, unlike domesticated bovine,

* Corresponding author: forcada@unizar.es most domesticated small ruminants have retained most of the physiological expressions of reproductive seasonality.

Sexual activity in sheep is strongly influenced by photoperiod, which is the main environmental factor responsible for the seasonality of reproduction in populations at high latitudes; however, sheep are spread around the world, and the general description of seasonal breeding in small ruminants cannot be applied universally. Almost $60 \%$ of the world's sheep are found between $35^{\circ} \mathrm{N}$ and $35^{\circ} \mathrm{S}$ [1], an area in which a reproductive strategy that is based solely on photoperiodic cues might not be the most suitable [2]. The climate between $35^{\circ} \mathrm{N}$ and $35^{\circ} \mathrm{S}$, which some refer to as "Mediterranean" [3], can extend 
to $40-41^{\circ} \mathrm{N}$. The region is characterised by seasonality in food availability (influenced by wet winters and springs and dry summers), and weight loss by sheep in the autumn, the natural mating season. Therefore, Mediterranean breeds are adapted to reproductive strategies because of their reduced reproductive seasonality, and their response to photoperiod can be modulated by other environmental (nutrition) or social (male effect or permanent contact ewesrams) factors [4]. Thus, Mediterranean breeds are adapted to intensive production and accelerated lambing programs.

\section{ROLE OF PHOTOPERIOD IN REPRODUCTIVE SEASONALITY}

In sheep, the experimental modification of photoperiod, without a change in other factors can shift the timing of the breeding season. The reversal of the annual photoperiodic cycle causes the reproductive season to shift by six months [5]. In addition, within six months, ewes exposed to light regimes that provided a natural annual variation in daylength, have two breeding seasons per year [6]. Furthermore, alternating periods of short ( $8 \mathrm{~h}$ of light) and long (16 h of light) days induce periods of sexual activity and anoestrus respectively, following a latency period between every change of photoperiod (e.g., periods of sexual activity begin $50 \mathrm{~d}$ after the start of the short-day light regime) [7]. It is clear that short days are stimulatory and long days are inhibitory at short time.

Modifications to the activity of the hypothalamic-pituitary axis through changes in pulsatile gonadotrophin releasing hormone $(\mathrm{GnRH})$ and luteinizing hormone (LH) control the seasonal changes in ovine reproductive condition. Such modifications reflect differences in sensitivity to the negative feedback of circulating oestradiol [8]. The use of ovariectomised-oestradiol implanted
$(\mathrm{OVX}+\mathrm{E} 2)$ ewes insures a constant release of oestradiol and provides a suitable model for studying the effect of photoperiod on the secretion of GnRH-LH. Furthermore, prolonged stimulatory (short days) or inhibitory (long days) photoperiods induce states of photorefractoriness, which changes the reproductive state of the ewes [9, 10]. Refractoriness seems to reflect the expression of an endogenous annual rhythm, which is observed in ewes exposed to prolonged, constant long and short photoperiods. Animals in these conditions continue to display cyclical variations in reproductive activity, although not synchronised among animals, and have periods differing synchronisation from 1 year [11]. Particular segments of the annual photoperiodic cycle seem to be more relevant in the synchronisation of endogenous rhythms [12,13]. Thus, the increasing daylength in the spring might be responsible for the onset of the breeding season at the end of the summer, whereas the long, but decreasing daylengths from the summer solstice to the autumnal equinox seem to insure the normal duration of the subsequent reproductive season.

\section{SEASONAL REGULATION OF HYPOTHALAMIC ACTIVITY}

The pineal gland is directly involved in the ewe's perception of photoperiod. The retina receives photoperiodic information, which follows a multi-step neural pathway to the pineal gland, where the message modulates the rhythm of melatonin secretion [14]. The duration of secretion differs between long and short days because melatonin is released at night, only. Variations in the duration of melatonin secretion are processed neurally and regulate the secretion of GnRH. Melatonin is released in the Galen vein and in the cerebrospinal fluid, where concentrations are 20 times greater 
than in the jugular vein [15]. The relative importance of the two pathways in modulating reproductive activity remains unresolved.

In the ovary-intact ewe, low pulsatility of GnRH and LH occurs during the luteal phase of the oestrous cycle because of the negative feedback effect of elevated levels of circulating progesterone [16]. During anoestrus, the frequency of episodic GnRH and LH secretions is extremely low (pulses every 6-12 h) despite the lack of corpora lutea and the resulting absence of the progesterone in plasma [17]. The low circulating concentrations of follicular oestradiol are sufficient to maintain a reduced GnRH pulsatility outside of the breeding season [8]. Thereafter, the low pulse frequency does not follow an alteration in the secretory activity of the hypothalamus because ovariectomised ewes increase GnRH pulsatility during anoestrus [16]. Reduced plasma oestradiol concentrations do not reduce GnRH secretion in the reproductive season [17], thus differential hypothalamic sensitivity (high in anoestrus and low in the breeding season) is, perhaps, the major neuroendocrine determinants of seasonal changes in ovarian cyclicity [8].

Sixty per cent of the population of $\mathrm{GnRH}$ cell bodies are located in the preoptic area of the sheep brain and about $15 \%$ of the GnRH neurons are detected in the mediobasal hypothalamus [18]. It has been shown that the GnRH cell from the preoptic area undergoes morphological changes in relation to the season, with an increase in the inervation of preoptic GnRH elements during the breeding season [19], although the involvement of these anatomical changes in the inhibition of LH release during anoestrus remains to be elucidated.

It has been demonstrated in sheep that melatonin acts in the mediobasal hypothalamus to modulate pulsatile GnRH secretion [20]. Parallel to the effect of artificial photoperiodic treatments, the effect of melatonin implants to improve the $\mathrm{GnRH}$ secretory activity of the hypothalamus of anoestric ewes subjected to a long-day light regime requires a latency period not lower than 40-50 days [21].

\section{NUTRITIONAL MODIFICATION OF REPRODUCTIVE SEASONALITY IN SHEEP}

The beneficial effects of nutrition on reproduction in sheep are well known. In particular, nutrition is one of the main factors affecting ovulation rate, even over a very short time (4-6 d) [22], although this effect is not very consistent among or even within laboratories [23]. The effect of nutrition on ovulation rate is more evident over a period and when the nutritional treatments are done in the transitional period between anoestrus (seasonal or lactational) and the breeding season [24, 25].

Nutrition has a smaller influence on sexual activity than on ovulation rate. Evidently, only severe malnutrition can significantly extend the length of the seasonal anoestrous period, which is mainly attributed to an earlier end of the reproductive season [26]. In contrast, the modification of reproductive seasonality in ewes that have a moderate level of fat reserves using the level of nutrition as the only management tool seems to be difficult.

In the Mediterranean environment, however, it is possible to overcome the regulating effect of photoperiod on reproductive seasonality in ewes that have a moderately high level of fat reserves. Our results show a consistent reduction (64 vs. $113 \mathrm{~d} ; P<0.05)$ in the duration of seasonal anoestrus in ewes maintained from November to September at a constant, moderately high body condition score (BC) (2.9) when compared to females having a lower (but commercially viable) BC (2.3) [24] (Fig. 1). In our study, liveweight was kept constant throughout 
Oestrous activity, \%

Ovulation rate

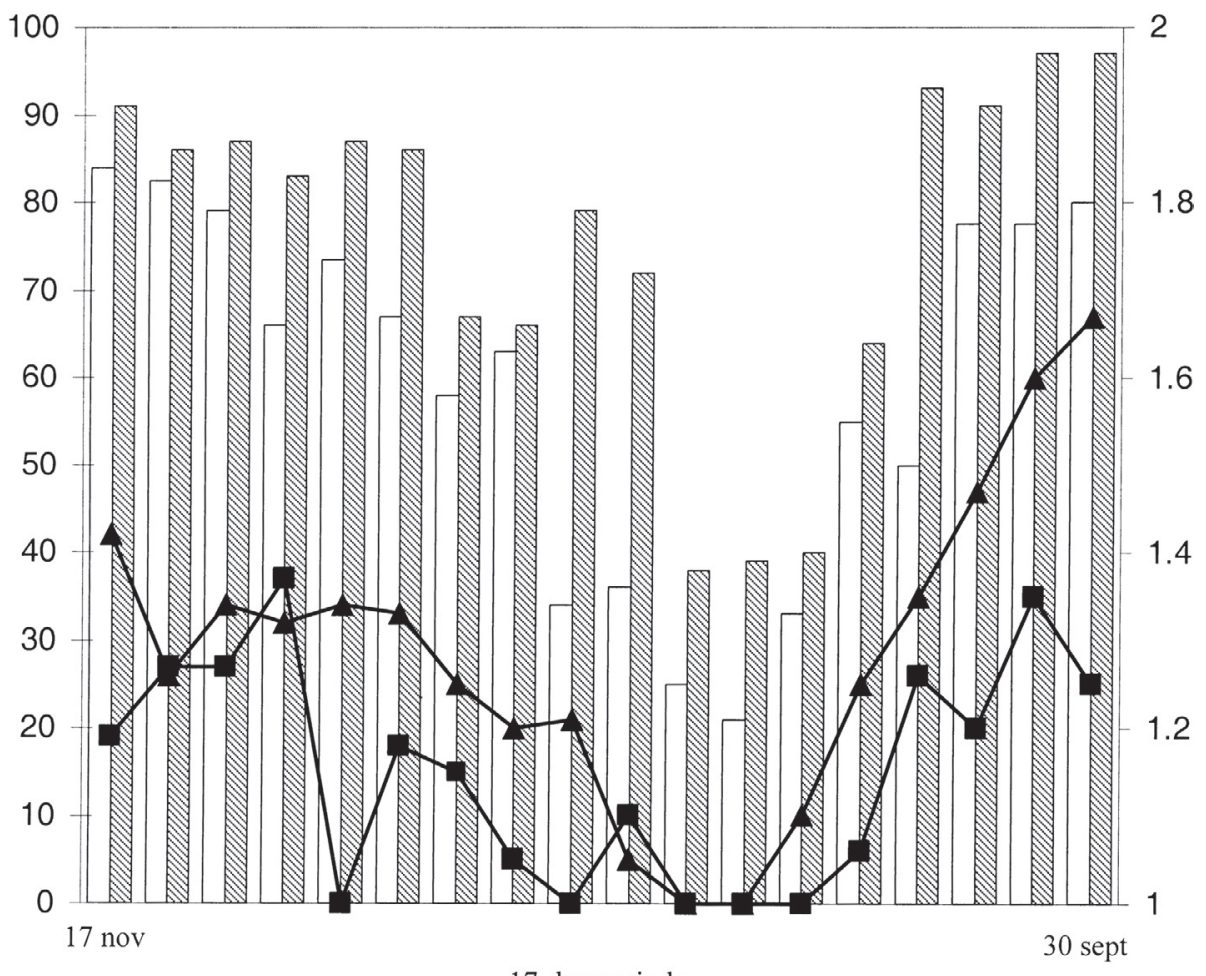

17-day periods

Figure 1. Oestrous activity and ovulation rate of Rasa Aragonesa ewes maintained at two constant levels of body condition (BC) throughout the year: moderately high (2.8) (filled bars and $\mathbf{\Lambda}$, respectively) and moderately low (2.3) (white bars and $\mathbf{m}$, respectively). The length of seasonal anoestrus was significantly shortened by a moderately high BC: 64 vs. 113 days; $P<0.05$ ). Adapted from Forcada et al. [24].

the experiment, with a between-group difference of $6 \mathrm{~kg}$ (48 vs. $42 \mathrm{~kg}$ ). The greatest differences in sexual activity occurred in the transitional period between the seasonal anoestrus and the reproductive season, when a moderately high $\mathrm{BC}$ induced a significant increase in the proportion of ewes in oestrus.

The effect of a high level of body fat reserves on sexual activity seems to be consistent among Mediterranean breeds and acts more though delaying the onset of seasonal anoestrus than by advancing the start of the new reproductive season, which is less modified by nutrition [24, 27, 28] and, probably, more strongly regulated by photoperiod. The inhibitory and synchronising effects of increasing daylength and long days between the spring equinox and the summer solstice on sexual activity [12] appear to be difficult to overcome using nutrition only, even in Mediterranean genotypes. Indeed, in several Mediterranean breeds of sheep, improving nutrition after weaning has consistently failed to advance the onset of sexual activity following lambings in seasonal anoestrus [25, 29]. In one study, however, malnutrition during the 
suckling period caused a significant reduction in plasma LH concentrations in ewes lambing in the mid-breeding season [30]. Furthermore, those undernourished ewes were unable to reactivate their cyclicity before the onset of the seasonal anoestrus.

\section{MECHANISMS OF ACTION OF NUTRITION ON SEASONALITY OF REPRODUCTION}

By using OVX+E2 ewes at the beginning of the breeding season, Rhind et al. [31] demonstrated that high food intake or high body fat induces an increase in mean plasma concentrations and pulse frequency of LH without modifying the sensitivity of the pituitary to GnRH. Thus, adequate nutrition caused a significant reduction in hypothalamic sensitivity to the negative feedback of oestradiol. By using OVX+E2 Rasa Aragonesa ewes at the beginning and the end of the seasonal anoestrus following a twoweek period of overfeeding, we observed the same effect on plasma LH concentrations, although the effects of nutrition on LH pulse frequency were not significant; possibly, because of the short time over which the nutritional treatments were administered [32]. Although high food intake appears to have a stronger effect on LH secretions than does a constant level of body fat $[33,34]$, the initial increase in LH secretion induced by a high food intake is maintained for only a few weeks, despite consistent increases in body mass caused by high food intake. That effect occurred in intact $[2,35]$ and in castrated/oestradiolimplanted animals [34], which probably reflects long-term adaptations that allow animals to reach a new equilibrium in energy balance after their nutritional state has changed. Thus, the hypothalamus might have a nutritional 'memory' that can influence subsequent responses to a given level of nutrition.
To better understand the mechanisms by which nutrition modifies the sensitivity of the hypothalamus to oestradiol negative feedback during seasonal anoestrus, we propose several areas for investigation.

\subsection{Modification of circulating oestrogenic activity}

Differences in the rate of clearance, rather than differences in secretion levels, can explain the apparent inverse relationship between nutrition and peripheral steroid concentrations. In ewes, reductions in plasma progesterone levels following overfeeding are a consequence of higher metabolism of the steroid by the liver [36]. Enhanced nutrition might increase the clearance of oestrogen [37]. In sheep, oestradiol- $17 \beta$ is converted very efficiently by the liver to oestradiol-17 $\alpha$. Relatively little oestrogen is excreted in the urine, and over $80 \%$ of the oestrogen is excreted as free oestradiol-17 $\alpha$ in the faeces. In ewes, food restriction is clearly associated with slower faecal excretion of oestrogen and higher plasma concentrations of oestradiol-17 $\alpha$ [38], which might undergo back-conversion to estrone and oestradiol$17 \beta$ [39]. Thus, high food intake or a high body fat might be associated with reduced estrogenic activity in plasma, which leads to lower hypothalamic sensitivity to the negative feedback of oestradiol.

\subsection{Role of endogenous opioids and the dopaminergic system}

In sheep, in the presence of oestradiol, endogenous opioids are involved in the inhibition of LH secretion during the prepubertal [40] and early postpartum [30] periods because blocking of opiate receptors using the antagonist naloxone increases LH pulse frequency. During seasonal anoestrus, however, neither intact nor 
$\mathrm{OVX}+\mathrm{E} 2$ adult ewes respond to treatment with opioid antagonists [41, 42], which suggests the involvement of other neuronal mechanisms (dopaminergic, serotoninergic) that prevent LH secretion from being a naloxone-reversible process during anoestrus [42]. In OVX+E2 adult ewes of a Mediterranean breed, we found that naloxone induced a significant increase in $\mathrm{LH}$ pulse frequency in early and late anoestrus, which was independent of the level of food intake [32]. Thus, in Mediterranean breeds that have a short anestrous, those nonopioid mechanisms are either unrelated to the opioidergic pathways or unable to mask the disinhibition of LH pulse frequency in response to naloxone.

The dopaminergic system is involved in the suppression of $\mathrm{LH}$ secretion by oestradiol during anoestrus, particularly, at the end of the breeding season. In $\mathrm{OVX}+\mathrm{E} 2$ adult ewes in a state of photorefractoriness to short days, the dopamine antagonist pimozide can increase $\mathrm{LH}$ pulse frequency $[43,44]$; however, Gayrard et al. [45] reported an increase in the activity of tyrosine hydroxylase (the ratelimiting enzyme in the synthesis of catecholamines) related to the inhibition of $\mathrm{LH}$ secretion by oestradiol in ewes subjected to an inhibitory photoperiod of long days.

In OVX+E2 Mediterranean ewes during the early and late seasonal anoestrus, we demonstrated the role of the dopaminergic system in the inhibition of LH pulse frequency [32]; however, in our study, the effect of pimozide on LH secretion seemed to be higher in ewes that received a high level of food intake, which indicated that overfeeding probably reduced the role of additional neural systems in the inhibition of LH secretion in the transitional periods between anoestrus and the breeding season. In fact, in underfed Mediterranean $\mathrm{OVX}+\mathrm{E} 2$ ewes implanted with melatonin, treatment with pimozide can restore LH secretion levels to the levels observed in overfed ewes before the treatment with the dopaminergic antagonist [46].

\subsection{Nutritional signals influencing the control of GnRH release}

In attempting to identify the mechanisms that might link GnRH-LH release to nutritional status, some have postulated that blood-borne signals that reflect metabolic status might be involved. In particular, Hall et al. [47] reported that abomasal infusion of the amino acid tyrosine in nutritionally growth-restricted and ovariectomised ewe lambs induced a significant increase in LH pulse frequency as early as $10 \mathrm{~d}$ after the start of the treatment. They postulated that increased plasma concentrations of tyrosine might reduce the availability of tryptophan to the central nervous system by competing for carrier sites to cross the blood-brain barrier [48], and negatively influence the synthesis of serotonin, which is closely associated with the availability of tryptophan [49]. Serotonin mediates the steroid-dependent inhibition of LH secretion during seasonal anoestrus [44, 50], therefore, increased tyrosine concentrations can influence $\mathrm{LH}$ secretion by reducing the production of serotonin. Furthermore, tyrosine is an important gluconeogenic amino acid. If a high level of nutrition can improve reproductive parameters, it is always associated with a significant increase in plasma concentrations of tyrosine [51].

\subsection{The role of leptin in the nutritional regulation of GnRH-LH secretion}

In domesticated ruminants, leptin is produced mainly in white adipose tissue and secreted into circulating blood at concentrations that are influenced by genetic, nutritional, physiological, and environmental factors. In sheep, malnutrition 
reduces gene expression and concentrations of circulating plasma leptin $[52,53]$. Furthermore, in sheep subjected to a longday photoperiod, leptin concentrations are higher $[54,55]$, which probably reflects photoperiod-driven changes in intake and adiposity because food restrictions during long days reduce leptin concentrations to levels similar to those that occur during short-days [55].

In OVX+E2 male sheep, Archer et al. [34] observed higher plasma leptin concentrations in animals that had high BC than in sheep that had low BC and following exposure to a high vs. a low level of food intake for 4 weeks. However, only in the latter scenario was GnRH-LH secretion stimulated, although glucose and insulin plasma concentrations were significantly increased in both cases. These results imply that the reproductive neuroendocrine axis can detect an acute increase in nutritional condition, which might be mediated by changes in the leptin signal. Apparently, however, the stimulatory effect of leptin on LH secretion in ruminants is limited to medium-term periods of nutritional stress [56].

Both intracerebroventricular [57] and peripheral [58] infusions of leptin stimulate dose-dependent increases in circulating insulin [58]. Moreover, direct ovarian arterial infusion of leptin reduced ovarian oestradiol secretion [59], probably by inhibiting the IGF-I-mediated enhancement of FSH-stimulated oestradiol synthesis by ovine granulosa cells [60]. These effects might explain the static (medium term) effects of nutrition on reproduction. Ewes that have a high $\mathrm{BC}$ have a high ovulation rate that is accompanied by high FSH and low oestradiol concentrations compared to females that have a low BC [23]. Reduced oestradiol production is likely associated with the higher leptin levels exhibited by ewes that have high body fat and lower steroid concentrations might reduce the negative feedback at the hypothalamus- pituitary axis, thereby, increasing LH and FSH concentrations. In fact, neuropeptide Y (NPY) can mediate the effects of body fat on GnRH-LH secretion. Both leptin [61] and high body condition [34] reduce NPY gene expression in sheep, and this neuropeptide is involved in the inhibition of GnRH secretion in the presence of oestradiol [62]. Synaptic contacts with GnRH neurons exist for NPY in sheep [63].

In contrast, the short-term effect of nutrition on GnRH-LH secretion is not mediated by changes in the oestradiol feedback system, but increases in concentrations of glucose, insulin, and leptin, which act more at a local level in stimulating glucose uptake [23]. Archer et al. [64] reported that a peripheral glucose infusion caused higher plasma concentrations of leptin and insulin in oestradiol-implanted, castrated male sheep; however, the effect of such infusion on LH secretion was strongly influenced by photoperiod. Glucose increased LH pulse frequency $(P<0.01)$ and amplitude $(P<0.01)$ and reduced the amount of NPY mRNA $(P<0.05)$, but the effects only occurred when animals were in a photoperiodic state of early anoestrus and not when under a photoperiod characteristic of the end of anoestrus or the beginning of the breeding season.

\section{CONCLUSIONS}

Nutrition seems to have a moderate effect on the seasonality of reproduction in Mediterranean breeds of sheep; however, the response can vary depending on the season. Nutritional stimulation during seasonal anoestrus cannot always overcome photoperiodic inhibition, although good nutrition can result in a higher proportion of cyclic ewes during this period. The highest receptivity to nutritional stimulation in terms of reducing reproductive seasonality occurs in the transitional periods between 
anoestrus and the reproductive season, particularly at the end of the latter, when photoperiod influence is waning. At the end of the seasonal anoestrus, photoperiod plays an important role in regulating the onset of the breeding season, although this is the best time to use nutrition manipulation to improve ovulation rate. It is reasonable to postulate that both immediate and static effects of nutrition on sexual activity can be additive.

\section{ACKNOWLEDGEMENTS}

Some of the results presented have been derived from several grants from CICYT (Spain).

\section{REFERENCES}

[1] Lindsay DR. Reproduction in the sheep and goat. In: Cupps PT (Ed), Reproduction in domestic animals, 4th ed, Academic Press, San Diego, 1991, p 491-515.

[2] Martin GB, Walkden-Brown SW, Boukhliq R, Tjondronegoro S, Miller DW, Fisher JS, Hötzel MJ, Restall BJ, Adams NR. Nonphotoperiodic inputs into seasonal breeding in male ruminants. In: Davey KG, Peter RE, Tobe SS (Eds), Perspectives in comparative endocrinology, National Research Council of Canada, Otawa, 1994, p 574-585.

[3] Martin GB, Hötzel MJ, Blache D, WalkdenBrown SW, Blackberry MA, Boukhliq R, Fisher JS, Miller DW. Determinants of the annual pattern of reproduction in mature male Merino and Suffolk sheep: modification of responses to photoperiod by an annual cycle in food supply. Reprod Fertil Dev 2002, 14: 165-175.

[4] Lindsay DR. Environment and reproductive behaviour. Anim Reprod Sci 1996, 42: 1-12.

[5] Yeates NTM. The breeding season of the ewe with particular reference to its modification by artificial light. J Agric Sci Camb 1949, 39: $1-43$.

[6] Mauleon P, Rougeot J. Régulation des saisons sexuelles chez des brebis de races différentes au moyen de divers rythmes lumineux. Ann Biol Anim Bioch Biophys 1962, 2: 209-222.
[7] Chemineau P, Pelletier J, Guerin Y, Colas G, Ravault JP, Touré G, Almeida G, Thimonier J, Ortavant R. Photoperiodic and melatonin treatments for the control of seasonal reproduction in sheep and goats. Reprod Nutr Dev 1988, 28: 409-422.

[8] Karsch FJ, Dahl GE, Evans NP, Manning JM, Mayfield KP, Moenter SM, Foster DL. Seasonal changes in gonadotropin-releasing hormone secretion in the ewe. Alteration in response to the negative feedback action of estradiol. Biol Reprod 1993, 49: 1377-1383.

[9] Robinson JE, Karsch FJ. Refractoriness to inductive day lengths terminates the breeding season of the Suffolk ewe. Biol Reprod 1984, 31: 656-663.

[10] Robinson JE, Wayne NL, Karsch FJ. Refractoriness to inhibitory daylength initiates the breeding season of the Suffolk ewe. Biol Reprod 1985, 33: 324-334.

[11] Karsch FJ, Robinson JE, Woodfill CJI, Brown MB. Circannual cycles of luteinizing hormone and prolactin secretion in ewes during a prolonged exposure to a fixed photoperiod: evidence for an endogenous reproductive rhythm. Biol Reprod 1989, 41: 1034-1046.

[12] Malpaux B, Robinson JE, Wayne NL, Karsch FJ. Regulation of the onset of the breeding season of the ewe: importance of long days and of an endogenous reproductive rhythm. J Endocrinol 1989, 122: 269-278.

[13] Wayne NL, Malpaux B, Karsch FJ. Photoperiodic requirements for timing the onset and duration of the breeding season of the ewe: synchronization of an endogenous rhythm of reproduction. J Comp Physiol 1990, A166: 835-842.

[14] Karsch FJ, Bittman EL, Foster DL, Goodman RL, Legan SJ, Robinson JE. Neuroendocrine basis of seasonal reproduction. Recent Prog Horm Res 1984, 40: 185-232.

[15] Skinner DC, Malpaux B. High melatonin concentrations in third ventricular cerebrospinal fluid are not due to Galen vein blood recirculating through the choroids plexus. Endocrinology 1999, 140: 43994405 .

[16] Karsch FJ, Cummins JT, Thomas GB, Clarke IJ. Steroid feedback inhibition of pulsatile secretion of gonadotropin-releasing hormone in the ewe. Biol Reprod 1987, 36: 1207-1218.

[17] Barrell GK, Moenter SM, Caraty A, Karsch FJ. Seasonal changes of gonadotropin 
releasing hormone secretion in the ewe. Biol Reprod 1992, 46: 1130-1135.

[18] Caldani M, Batailler M, Thiery JC, Dubois MP. LHRH-immunoreactive structures in the sheep brain. Histochemistry 1988, 89: 129_ 139.

[19] Xiong JJ, Karsch FJ, Lehman NM. Evidence for seasonal plasticity in the gonadotropinreleasing hormone $(\mathrm{GnRH})$ system of the ewe: changes in synaptic inputs onto $\mathrm{GnRH}$ neurons. Endocrinology 1997, 138: 12401250.

[20] Malpaux B., Daveau A, Maurice F, Gayrard V, Thiery JC. Short days effects of melatonin on luteinizing hormone secretion in the ewe: evidence for central sites of action in the mediobasal hypothalamus. Biol Reprod 1993, 48: 752-760.

[21] Viguié C, Caraty A, Locatelli A, Malpaux B. Regulation of LHRH secretion by melatonin in the ewe. I. Simultaneous delayed increase in LHRH and $\mathrm{LH}$ pulsatile secretion. Biol Reprod 1995, 52: 1114-1120.

[22] Oldham CM, Lindsay DR. The minimum period of intake of lupin grain required by ewes to increase their ovulation rate when grazing dry summer pasture. In: Lindsay DR, Pearce DT (Eds), Reproduction in sheep, Australian Academy of Science, Australian Wool Corporation, Canberra, 1984, p 274 276.

[23] Viñoles C, Forsberg M, Martin GB, Cajarville C, Repetto J, Meikle A. Shortterm nutritional supplementation of ewes in low body condition affects follicle development due to an increase in glucose and metabolic hormones. Reproduction 2005, 129: 299-309.

[24] Forcada F, Abecia JA, Sierra I. Seasonal changes in oestrous activity and ovulation rate in Rasa Aragonesa ewes maintained at two different body condition levels. Small Ruminant Res 1992, 8: 313-324.

[25] Abecia JA, Forcada F, Zarazaga L. A note on the effect of level of nutrition after weaning on the resumption of reproductive activity by ewes of two Spanish breeds lambing in spring. Anim Prod 1993, 56: 273-276.

[26] Knight TW, Hall DHR, Wilson LD. Effects of teasing and nutrition on the duration of the breeding season in Romney ewes. Proc NZ Soc Anim Prod 1983, 43: 17-19.

[27] Montgomery GW, Scott IC, Johnstone PD. Seasonal changes in ovulation rate in Coopworth ewes maintained at different liveweights. Anim Reprod Sci 1988, 17: 197-205.
[28] Rondón Z, Forcada F, Zarazaga L, Abecia JA, Lozano JM. Oestrous activity, ovulation rate and plasma melatonin concentrations in Rasa Aragonesa ewes maintained at two different and constant body condition score levels and implanted or reimplanted with melatonin. Anim Reprod Sci 1996, 41: 225236.

[29] Forcada F, Zarazaga L, Abecia JA. Effect of exogenous melatonin and plane of nutrition after weaning on estrous activity, endocrine status and ovulation rate in Salz ewes lambing in the seasonal anestrus. Theriogenology 1995, 43: 1179-1193.

[30] Lozano JM, Forcada F, Abecia JA. Opioidergic and nutritional involvement in the control of luteinizing hormone secretion of postpartum Rasa Aragonesa ewes lambing in the mid-breeding season. Anim Reprod Sci 1998, 52: 267-277.

[31] Rhind SM, McMillen S, McKelvey WAC. Effects of levels of food intake and body condition on the sensitivity of the hypothalamus and pituitary to ovarian-steroid feedback in ovariectomized ewes. Anim Prod 1991, 52: 115-125.

[32] Forcada F, Lozano JM, Abecia JA, Zarazaga L. Control of luteinizing hormone secretion in ewes by endogenous opioids and the dopaminergic system during short seasonal anoestrus: role of plane of nutrition. Anim Sci 1997, 65: 217-224.

[33] Rhind SM. Nutrition: its effects on reproductive performance and its hormonal control in female sheep and goats. In: Speedy AW (Ed), Progress in sheep and goat research, CAB International, Wallingford Oxon, UK, 1992, p 131-151.

[34] Archer ZA, Rhind SM, Findlay PA, Kyle CE, Thomas L. Contrasting effects of different levels of food intake and adiposity on LH secretion and hypothalamic gene expression in sheep. J Endocrinol 2002, 175: 383-393.

[35] Zhang S, Blache D, Blackberry MA, Martin GB. Body reserves affect the reproductive endocrine responses to an acute change in nutrition in mature male sheep. Anim Reprod Sci 2005, 88: 257-269.

[36] Parr RA, Cumming IA, Clarke IJ. Effects of maternal nutrition and plasma progesterone concentrations on survival and growth of the sheep embryo in early gestation. J Agric Sci Camb 1982, 98: 39-46.

[37] Thomas DL, Thomford PJ, Crickman JG, Cobb AR, Dziuk PJ. Effects of plane of nutrition and phenobarbital during the pre-mating 
period on reproduction in ewes fed differentially during the summer and mated in the fall. J Anim Sci 1987, 64: 1144-1152.

[38] Adams NR, Abordi JA, Briegel JR, Sanders MR. Effect of diet on the clearance of estradiol-17 $\beta$ in the ewe. Biol Reprod 1994, 51: 668-674.

[39] Kazama N, Longcope C. Metabolism of estrone and estradiol-17 $\beta$ in sheep. Endocrinology 1973, 91: 1450-1454.

[40] Ebling FJP, Schwartz ML, Foster DL. Endogenous opioid regulation of pulsatile LH secretion during sexual maduration in the female sheep. Endocrinology 1989, 125: 369-383.

[41] Trout WE, Malven PV. Effects of exogenous estradiol-17 $\beta$ and progesterone on naloxone-reversible inhibition of the release of luteinizing hormone in ewes. J Anim Sci 1987, 65: 1602-1609.

[42] Schall RE, Ebling FJP, Karsch FJ, Foster DL. Postpubertal maduration of endogenous opioid regulation of luteinizing hormone secretion in the female sheep. Biol Reprod 1991, 44: 760-768.

[43] Kao C, Schaeffer DJ, Jackson GL. Different neuroendocrine systems modulate pulsatile luteinizing hormone secretion in photosuppressed and photorefractory ewes. Biol Reprod 1992, 46: 425-434.

[44] Le Corre S, Chemineau P. Control of photoperiodic inhibition of luteinizing hormone secretion by dopaminergic and serotonergic systems in ovariectomized Île-de-France ewes supplemented with oestradiol. J Reprod Fertil 1993, 97: 367-373.

[45] Gayrard V, Malpaux B, Tillet Y, Thiéry JC. Estradiol increases tyrosine hydroxylase activity of the A15 nucleus dopaminergic neurons during long days in the ewe. Biol Reprod 1994, 50: 1168-1177.

[46] Forcada F, Zúñiga O, Abecia JA. The role of nutrition in the regulation of $\mathrm{LH}$ secretion during anestrus by the serotoninergic and dopaminergic systems in Mediterranean ewes treated with melatonin. Theriogenology 2002, 58: 1303-1313.

[47] Hall JB, Schillo KK, Hileman SM, Boling JA. Does tyrosine act as a nutritional signal mediating the effects of increased feed intake on luteinizing hormone patterns in growth-restricted lambs? Biol Reprod 1992, 46: 573-579.

[48] Pardridge WM. Brain metabolism: a perspective from the blood-brain barrier. Physiol Rev 1983, 63: 1481-1535.
[49] Fernstrom JD, Wurtman RJ. Brain serotonin content: physiological regulation by plasma neutral amino acids. Science 1972, 178: 414-416.

[50] Le Corre S, Chemineau P. Serotonergic $5 \mathrm{HT}_{2}$ receptors mediate the inhibitory action of serotonin on luteinizing hormone secretion in ovariectomized, estradiol-treated ewes that are refractory to short days. Biol Reprod 1993, 49: 140-147.

[51] Downing JA, Joss J, Connell P, Scaramuzzi RJ. Ovulation rate and the concentrations of gonadotrophic and metabolic hormones in ewes fed lupin grain. J Reprod Fertil 1995, 103: 137-145.

[52] Blache D, Tellam R, Chagas LM, Blackberry MA, Vercoe PV, Martin GB. Level of nutrition affects leptin concentrations in plasma and cerebrospinal fluid in sheep. $\mathbf{J}$ Endocrinol 2000, 165: 625-637.

[53] Delavaud C, Bocquier F, Chilliard Y, Keisler DH, Gertler A, Kann G. Plasma leptin determination in ruminants: effects of nutritional status and body fatness on plasma leptin concentration assessed by a specific RIA in sheep. J Endocrinol 2000, 165: 519-526.

[54] Bocquier F, Bonnet M, Faulconnier Y, Guerre-Millo M, Martin P, Chilliard Y. Effects of photoperiod and feeding level on perirenal adipose tissue metabolic activity and leptin synthesis in the ovariectomized ewe. Reprod Nutr Dev 1998, 38: 489-498.

[55] Marie M, Findlay PA, Thomas L, Adam CL. Daily patterns of plasma leptin in sheep: effects of photoperiod and food intake. $\mathrm{J}$ Endocrinol 2001, 170: 277-286.

[56] Henry BA, Goding JW, Tilbrook AJ, Dunshea FR, Blache D, Clarke IJ. Leptinmediated effects of undernutrition or fasting on luteinizing hormone and growth hormone secretion in ovariectomized ewes depend on the duration of metabolic perturbation. J. Neuroendocrinol 2004, 16: 244-255.

[57] Amstalden M, Garcia MR, Stanko RL, Niezielski SE, Morrison CD, Keisler DH, Williams GL. Central infusion of recombinant ovine leptin normalizes plasma insulin and stimulates a novel hypersecretion of luteinizing hormone after short-term fasting in mature beef cows. Biol Reprod 2002, 66:1555-1561.

[58] Zieba DA, Amstalden M, Maciel MN, Keisler DH, Raver N, Gertler A, Williams GL. Divergent effects of leptin on luteinizing hormone and insulin secretion are dose dependent. Exp Biol Med 2003, 228: 325330. 
[59] Kendall NR, Gutiérrez CG, Scaramuzzi RJ Baird DT, Webb R, Campbell BK. Direct in vivo effects of leptin on ovarian steroidogenesis in sheep. Reproduction 2004, 128: 757-765.

[60] Zieba DA, Amstalden M, Williams GL. Regulatory roles of leptin in reproduction and metabolism: a comparative review. Domest Anim Endocrin 2005, 29: 166-185.

[61] Henry BA, Goding JW, Alexander WS, Tilbrook AJ, Canny BJ, Dunshea F, Rao A, Mansell A, Clarke IJ. Central administration of leptin to ovariectomized ewes inhibits food intake without affecting the secretion of hormones from the pituitary gland: evidence for a dissociation of effects on appetite and neuroendocrine function. Endocrinology 1999, 140: 1175-1182.
[62] McShane TM, May T, Miner JL, Keisler DH. Central actions of neuropeptide-Y may provide a neuromodulatory link between nutrition and reproduction. Biol Reprod 1992, 46: 1151-1157.

[63] Tillet Y, Caldani M, Batailler M. Anatomical relationships of monoaminergic and neuropeptide Y-containing fibres with luteinizing hormone-releasing hormone systems in the preoptic area of the sheep brain: immunohistochemical studies. J Chem Neuroanat 1989, 2: 319-326.

[64] Archer ZA, Rhind SM, Findlay PA, Kyle CE, Barber MC, Adam CL. Hypothalamic responses to peripheral glucose infusion in food-restricted sheep are influenced by photoperiod. J Endocrinol 2005, 184: 515-525.

To access this journal online: www.edpsciences.org 